https:/ / doi.org/10.18485/iipe_euchanges.2021.ch6

\title{
NATO VS. RUSSIA: \\ IMPACT ON BALKAN REGIONAL SECURITY
}

\author{
Elena S. PONOMAREVA ${ }^{1}$ \\ Dušan PROROKOVIĆ ${ }^{2}$
}

\begin{abstract}
NATO, led by the US, and Russia are important factors in the regional security of the Balkans and all Balkan states individually. In the post-bipolar world order, which is marked by strong US domination after the collapse of the USSR, Russia's influence has weakened. However, by stabilizing the internal situation and then consolidating its position in international relations, Russia has returned to the scene and used the military, political (including soft power and cultural ties) and economic power (which is primarily visible in the energy sector) to restore its presence in the region of the Balkans, which is especially noticeable after 2008. However, due to almost two decades of American domination, the regional security dynamics have changed greatly in relation to the time of bipolarity, and part of the Balkan states that belonged to the Eastern Bloc or emerged from the disintegration of Yugoslavia have already become NATO members (Bulgaria, Romania, Albania, Croatia, Slovenia, Montenegro, and North Macedonia). In such circumstances, the United States has an advantage. They are a key factor in the regional security of the Balkans and they are trying to prevent the growth of Russian influence. This research will explain the relationship between NATO and Russia, their long-term goals in the region, as well as the causes of lasting rivalry. The general hypothesis of this research is: the conflict formation within which the long-
\end{abstract}

${ }^{1}$ Professor, Moscow State Institute of International Relations (University), Moscow, Russia. E-mail: nastya304@mail.ru

${ }^{2}$ Research Fellow, Institute of International Politics and Economics, Belgrade, Serbia. E-mail: dusan.prorokovic@diplomacy.bg.ac.rs

The paper presents findings of a study developed as a part of the research project "Serbia and challenges in international relations in 2021", financed by the Ministry of Education, Science, and Technological Development of the Republic of Serbia, and conducted by Institute of International Politics and Economics, Belgrade. 
term interests of NATO and Russia are opposed will be maintained in the long run, and this will be reflected on the regional security of the Balkans. The historical method, comparative method and qualitative content analysis were used in the research, as well as modelling in the context of the future foreign policy positioning of the US and Russia and reflections on regional security. The conclusion of the authors is that the United States has no interest in stopping the planned expansion, while on the other hand, Russia is not in a position to allow them to do so. Because of everything, the Balkans remain a region where the establishment of a kind of balance of power between NATO and Russia is being monitored.

Keywords: NATO, USA, Russia, regional security, Balkans.

\section{THE BALKANS IN THE NEW POST BIPOLAR WORLD ORDER: NATO’S REGIONAL EXPANSION}

The only region to which NATO has been continuously expanding in the last 15 years is the Balkans! The last 'big enlargement' took place in 2004, when seven countries from Central and Eastern Europe were admitted to membership. At that time, Bulgaria, Romania and Slovenia became part of NATO. Since then, three 'small waves' of admission of new Balkan states have followed (Albania and Croatia in 2009, Montenegro in 2017, and North Macedonia in 2020). The process of NATO expansion in the Balkans is shown in Table 1. (Table compiled according to: Proroković, 2018, pp. 557-579)

TABLE 1: NATO EXPANSION TO THE BALKANS (1952-2004-2020)

\begin{tabular}{|l|c|c|}
\hline Country & In NATO since & \multicolumn{1}{|c|}{ Geostrategic significance for NATO } \\
\hline Greece & 1952 & $\begin{array}{l}\text { Securing a position in the Eastern Mediterranean; } \\
\text { surveillance of communist states in the immediate } \\
\text { vicinity (Bulgaria, Yugoslavia, Albania); control of } \\
\text { Otranto; harmonization of foreign and security } \\
\text { policy with Turkey in order to prevent the outbreak } \\
\text { of a large-scale interstate conflict; further securing } \\
\text { control of the Dardanelles and the Bosporus. }\end{array}$ \\
\hline Bulgaria & 2004 & $\begin{array}{l}\text { Access to the Black Sea coast; control of the strategic } \\
\text { direction from the Adriatic to the Black Sea; } \\
\text { ensuring access to the Middle East; approaching the } \\
\text { southwestern border of Russia. }\end{array}$ \\
\hline
\end{tabular}




\begin{tabular}{|c|c|c|}
\hline Country & In NATO since & Geostrategic significance for NATO \\
\hline Romania & 2004 & $\begin{array}{l}\text { Access to the Black Sea coast; control of the } \\
\text { strategic direction from Central Europe to the } \\
\text { Danube Delta; border control to Ukraine; } \\
\text { approaching the southwestern border of Russia. }\end{array}$ \\
\hline Slovenia & 2004 & $\begin{array}{l}\text { Securing a position in the northern Adriatic; } \\
\text { control of the strategic direction along the Sava } \\
\text { valley to the confluence with the Danube. }\end{array}$ \\
\hline Albania & 2009 & $\begin{array}{l}\text { Securing a position in the southern Adriatic } \\
\text { (control of Otranto); control of the strategic } \\
\text { direction from the Adriatic to the Black Sea } \\
\text { (through the territory of Kosovo and/or North } \\
\text { Macedonia to Bulgarian ports). }\end{array}$ \\
\hline Croatia & 2009 & $\begin{array}{l}\text { Securing a position in the central part of the } \\
\text { Adriatic waters; control of strategic routes from } \\
\text { the Pannonia Plain (Hungary) to the Adriatic Sea } \\
\text { (most pass through the territory of Bosnia and } \\
\text { Herzegovina); control of the strategic direction } \\
\text { along the Sava valley to the confluence with the } \\
\text { Danube. }\end{array}$ \\
\hline Montenegro & 2017 & $\begin{array}{l}\text { Establishment of the Adriatic Troika by linking } \\
\text { with Albania and Croatia, whereby NATO fully } \\
\text { ensures the communication route from the Gulf of } \\
\text { Trieste to the Peloponnese; control of the southern } \\
\text { branch of the Belgrade - Bar traffic route. }\end{array}$ \\
\hline $\begin{array}{l}\text { North } \\
\text { Macedonia }\end{array}$ & 2020 & $\begin{array}{l}\text { Completion of control over the southern route of } \\
\text { the strategic direction from the Adriatic to the } \\
\text { Black Sea; Control of the 'Balkan vertical' - a key } \\
\text { regional traffic route (Athens - Thessaloniki - } \\
\text { Skopje - Nis - Belgrade - Budapest) that stretches } \\
\text { through the Moravian-Vardar valley. }\end{array}$ \\
\hline
\end{tabular}

These activities are largely a consequence of earlier plans of the United States, mostly defined in the mid-nineties. The collapse of the Soviet Union was a 'geopolitical earthquake' on a global scale, affecting world politics as a whole. While, on the one hand, this 'earthquake' opened new perspectives for the United States, on the other hand, it was a 'geopolitical catastrophe' 
for Russia. During the time of bipolarity, the Balkans were in the zone of demarcation between the political West (NATO and the European Community) and the Eastern Bloc. Greece became a member of NATO in 1952, communist Yugoslavia articulated a 'policy of non-alignment' by maintaining relations with both geopolitical blocs, while Enver Hoxha's Albania first replaced a strategic partnership with the Soviet Union with a partnership with the People's Republic of China and later, from the 1970s it started to build 'its own path to socialism' by pursuing an isolationist policy. (Hoxha, 1979) Two Balkan states - Romania and Bulgaria - were in the Warsaw Pact.

The great 'geopolitical earthquake' marked the beginning of the 'reconfiguration' of this geographical area. 'The Balkans in general and former Yugoslavian countries in particular have been under significant geopolitical pressure of the political West since the end of the bipolar global order.' (Gajic\&Ponomareva, 2020, p. 70) The expansion of NATO and, through that, the expansion of American influence certainly had its geostrategic reasons. The Balkan Peninsula represents a contact zone between the Adriatic and the Black Sea waters in a narrower geographical sense (along the west-east axis), i.e., the Central European and Middle Eastern continental area in a broader sense (along the northwest-southeast axis). Domination over the Balkans made sense in the context of limiting the maintenance or a long-term penetration of the Russian influence in the border area (which represents the first step in the process of ensuring its own borders) - at the Caucasus-Black Sea direction (newly created independent states Georgia, Azerbaijan, Armenia, Ukraine, as well as USSR allies at the time - Romania and Bulgaria) and for uninterrupted planning of activities in the Middle East. Nevertheless, already in the early 1990s, it was obvious that NATO's expansion to the Balkan states and the US's 'political domination' over the entire peninsula could not pass easily and without consequences.

The dissolution of the USSR had as a direct consequence the collapse of socialistic Yugoslavia. First, Western attempts to weaken the Soviet mega-state have long been based on 'awakening' national feelings and promoting nationalism in separate republics, most notably in the three Baltic Soviet units, but to some extent also in Georgia, Ukraine, and Belarus. The nationalism of the peoples of Eastern Europe is becoming 'politically acceptable', even financially supported, it is a means of overthrowing the communist system. (Staniszkis, 2001) Therefore, no European communist federation 'survived', including Czechoslovakia. Only 'nation states', 
countries that have a smaller percentage of national minorities, are kept in the existing borders (and even in such states, like Romania with its Hungarian minority, had tensions and the threat of escalation). Communist Yugoslavia as a former 'quilt' became an arena for the 'clash of nationalisms' (Ponomarjova, 2019, p. 15) and numerous factors of internal character and local causes contributed to the flare-up of the conflict (for example, in Croatia, it was the suppressed fears of the Serb population rooted in horrific crimes committed by the Croatian Ustashas; in Kosovo, it was a desire for unification with Albania and the counter-reaction of the authorities in Belgrade, which abolish the previous constitutional powers of the province, etc.).

Secondly, Yugoslavia, although created by the will and desire of the dominant parts of the intellectual and political elites of the South Slavic people, still owed its survival more to geopolitical balance than to the conviction of those same elites whose priority was to preserve one state. (Stanković, 2009) Primarily, the revisionist policy of Germany and Hungary between the two world wars determined Great Britain and France to support the survival of Yugoslavia at any cost, and then after the 'parting' of Tito and Stalin in 1948, communist Yugoslavia became an important player in implementing the American concept of 'wedging'. When the Soviet Union no longer existed, there was no need for 'wedging', and therefore no need for keeping Yugoslavia alive at any cost. The internal conflict potential, well inflamed with nationalism, meant that the disintegration of Yugoslavia could not take place relatively peacefully as it was the case with Czechoslovakia.

The US hesitation to quickly and directly get involved in resolving the Yugoslav crisis while leaving the initiative to European countries that had completely different views (Germany versus France, plus Great Britain which calculatedly followed only its own line of interest), or catastrophic errors of assessment (no matter if they were accidental or intentional, such as putting pressure on Alija Izetbegović to withdraw his signature from Cutileiro's plan, which practically led to the immediate beginning of the war in Bosnia and Herzegovina) did not contribute to calming the situation on the ground, but on the contrary, it helped spreading the conflict and its escalation. (Kecmanović, 2017)

In the first phase of 'Yugoslav crisis management', American (geo) policy primarily started from the situation on the ground and with the 'bottom up' strategy it directed local conditions towards fulfilling its own goals. This meant that in this development of the situation, all actors had 
reasons for dissatisfaction, but also made certain gains (Croats carried out the largest ethnic cleansing in Europe after the Second World War, getting ethnically homogeneous territory of their independent state, but also remained without entity in $\mathrm{B} \& \mathrm{H}$; Muslims maintained $\mathrm{B} \& \mathrm{H}$ within the existing borders where they had the largest population, but the country remained divided into two entities; Serbs got an entity in B\&H with broad powers but experienced a tragedy in Croatia where the Republic of Serbian Krajina disappeared). From today's perspective, the Americans created a starting position not only to declare themselves 'guarantors of security' in the region because of their mediating role, but also to demonstrate to everyone in a bilateral format how they have to thank the US for their achievements. But in the second phase of 'managing the Yugoslav crisis', American diplomacy is moving to an 'up to down' strategy, ignoring local realities and trying to impose solutions. This primarily refers to the American engagement in Kosovo, which from the beginning was directed to provoking NATO military intervention by bringing official Belgrade into an impossible position (at the negotiations in Rambouillet, the Yugoslav delegation was essentially required to agree with the Albanian secession) (Mitić, 2003). Having in mind the epilogue of the Kosovo war and NATO aggression on the FR Yugoslavia, it is indisputable that the United States remained the 'guarantor of security' in the regional framework, and in that sense, they further strengthened their position. However, it is also clear that they lost the opportunity to offer anything to Serbia in a bilateral format since the Serbian corps had lost all confidence in the sincerity of American intentions. Therefore, by going from the 'bottom up' to the 'up to down' strategy, the US had additionally strengthened its influence among Muslims - Bosniaks, Croats and Albanians, but it has irreversibly lost its influence among Serbs. Hence, regardless of the great and to some extent externally supported political changes in Belgrade (the fall of Slobodan Milosević in 2000, the fall of Vojislav Koštunica in 2008, and the congratulations on the victory in the 2012 elections to Tomislav Nikolić by the EU few hours before polling stations were closed), a constant in Serbian politics remained that NATO membership is not an option.

Since 2007 and the mentioning of the military neutrality thesis in a parliamentary resolution concerning the preservation of territorial integrity (dedicated to the situation in Kosovo and Metohija), this formulation has become an official position and gradually gained some content (finally, it is elaborated in the National Security Strategy of the Republic of Serbia from 2018). Contrary to the successful NATO expansion, the Balkans also remained the region that (for the first time after the fall of the bipolar order) 
gave decisive resistance to NATO's further expansion and made a public stance that membership in this military alliance is not the only way to protect national security.

This research will explain the relationship between NATO and Russia, their long-term goals in the region, as well as the causes of lasting rivalry. The general hypothesis of this research is: the conflict formation within which the long-term interests of NATO and Russia are opposed will be maintained in the long run, and this will be reflected on the regional security of the Balkans. The historical method, comparative method and qualitative content analysis were used in the research, as well as modelling in the context of the future foreign policy positioning of the US and Russia and reflections on regional security.

\section{THE RUSSIAN COMEBACK: RENEWAL OF INFLUENCE AFTER 2006}

The articulation of Serbia's position on military neutrality is therefore influenced by historical reasons and current US geopolitical aspirations to complete the reconfiguration of the post-Yugoslav space (only four years after the aggression on the FR Yugoslavia, the US began political initiatives regarding Kosovo status, talks that should be completed by the 'Declaration of independence' and Belgrade's consent to that decision). On the other hand, this position is also influenced by the Russian stance that provides decisive support to Belgrade and thus strikes a balance in the conditions of very unpleasant NATO pressures regarding the 'Kosovo issue'. The title of this chapter mentions the 'Russian comeback', which is only somewhat true, as the real truth is that Russia has never left the Balkans (despite the shortcomings, this subtitle is kept as it reflects a kind of 'turnover' in Balkan geopolitics that occurred in 2006-2008).

Despite the hard position caused by the collapse of the Soviet Union, problems in the immediate neighbourhood (conflicts in Moldavia, Georgia, Tajikistan and between Azerbaijan and Armenia, tensions within Russia itself, the rise of nationalism and the status of the Russian population in most of the emerging states), and the real decline of military and economic power, Russia remained an 'active player' in the process of disintegration of Yugoslavia and the search for solutions to the crises in Croatia, B\&H, and Kosovo.

Russian ambassador Leonid Vladimirovich Kerestedzhiyants was a member of the so-called 'mini Contact Group', together with his American counterpart Peter W. Galbraith and German diplomat Geert-Hinrich 
Ahrens, a Group that was trying to come up with a peaceful solution to the conflict in Croatia (Ahrens, 2007, p. 165). In the end, these efforts resulted in Plan Z-4, which was not well accepted by the Serbs and Croats.

Russian diplomacy has been involved in resolving the war conflict in $\mathrm{B} \& \mathrm{H}$ from the very beginning, due to the fact that the role of the UN Security Council is unavoidable. The First Deputy Minister of Foreign Affairs of the Russian Federation, Igor Ivanov, was the co-chairman together with the EU Special Representative Karl Bildt to the Chief Negotiator Richard Holbrooke at the Dayton Peace Talks held in November 1995. (Bildt, 1998)

Among the other signatories of the Paris-Dayton Peace Agreement is Viktor Chernomyrdin, at that moment, the Prime Minister of Russia. Four years later, Chernomyrdin appears as a special representative of Russian President Boris Yeltsin during Martti Ahtisaari's mediation over the crisis in Kosovo and Metohija, and that work will influence the definition of UN Security Council Resolution 1244, which was eventually adopted.

Parallel with the change in the American approach and the transition to the 'up to down' strategy, Russia intensified its activities and gradually took a different course. More and more the 'conflicted' attitude was prevailing the previously dominant 'constructiveness' approach in the relation to the US. This was first seen during the Rambouillet talks, when Russia's envoy, Ambassador Boris Mayorski, disagreed with the 'US amendments' that included substantial acceptance of secession and was even more apparent on the sidelines of the UN, where Russia has shown absolute resilience to the US proposals to allow military intervention against the FR Yugoslavia under the flag of this international organization. (Proroković, 2019, pp. 237-245)

It must be admitted that 'from the very moment of Yugoslavia's breakup, Russia's position has been that of Serbophilia, although retroactively many decisions look too hasty and strategically ill-conceived. Such was, for example, the recognition of the independence of Bosnia and Herzegovina-despite the obvious inevitability of a bloody interethnic war. The Russian leadership signed the relevant documents on April 27, 1992, when sporadic conflicts had already taken place. The real war began a few days later, in May, immediately after the withdrawal of the Yugoslav People's Army.' (Ponomareva, 2020, p. 171) The analysis of the transcripts of conversations between Bill Clinton and Boris Yeltsin dated April 1996 to December 1999 provides sufficient proof that the March 1999 events could have taken a different course and the Kosovo issue could have been settled then and there. (Declassified Documents, 2018, pp. 432-436) 
The interesting information is that the Russian nuclear submarine K141 'Kursk' was sent to a secret mission in the Mediterranean Sea (the Fifth Fleet of the US Navy was in the waters as a 'striking fist' in the war against FR Yugoslavia) at the beginning of the war to approach NATO vessels unnoticed, and it has carried out the entrusted mission in full (Russia 24, 2020). This shocked NATO to the extent that the diversion of foreign services is still cited as a possible reason for the 'Kursk' tragedy during a routine exercise a year later in the Barents Sea (Voltskaya, 2020). The reason for this conclusion is the testimony of the then Admiral of the North Sea Fleet of the Russian Navy, Admiral Vyacheslav Popov, that 'Kursk' was sent to the 'Mediterranean mission' for political reasons, in order to put pressure on the United States and achieve a faster and more favourable diplomatic solution (Rossiya 24, 2020).

Resolution 1244 is a result of long and troublesome negotiations, organized in several different phases, but to a certain extent, it is also the work of the Russian foreign and security policy, which participated in this process from the very beginning and maintained it until the end, although exposed to numerous unpleasant pressures. It turns out that Russia's engagement on the Kosovo issue was in many ways the key to Moscow's future actions in the Balkans, and thus to the regional security. Namely, after 2001, Russia remained committed within the Contact Group to seeking a 'fair status solution' for Kosovo, which means first negotiations between the Serbian and Albanian sides, and then harmonization of positions. The United States viewed the negotiations as a mere means to reach the goal as soon as possible, to elaborate plans and prepare the public (both domestic and Balkan by using various channels for information distribution, including generous financial assistance to numerous media) for 'Kosovo's independence', and at some moments they tended to show excessive impatience (like putting deadlines to the mandate of Martti Ahtisaari as the UN Secretary General's Special Envoy for the Kosovo Status Negotiations, and then the three-month term of the Troika that succeeded Ahtisaari, a group of three diplomats representing the EU, US and Russia authorized to find in such a short time solution to this complex problem). (Jovanović, 2006) American diplomacy was not hiding that they were in a hurry. Kosovo is a topic that they would like to 'archive' and see the end of the whole thing in the act of admitting the 'state of Kosovo' to the UN. In this way, the position of the 'state of Kosovo' in international relations would be completely legalized, but at the same time, it would legitimize the NATO attack on FR Yugoslavia, which then would no longer be called aggression, but only and exclusively - humanitarian intervention. Russia responded to the 'American 
rush' and a large number of initiatives by referring to Resolution 1244 and insisting on international law, which meant very concrete support for Belgrade. In circumstances when all the most important western powers (US, Great Britain, France, Germany, Italy) and Turkey as an important actor of regional relations, are for the 'independence of Kosovo', (China is giving principal support to Belgrade, but is not engaging in any broader activities), Serbia does not have another ally among influential states beside Russia. In that sense, the strategic partnership with Moscow is seen as a logical solution that should serve as a long-term amortization of 'western pressure'. Having in mind that Serbia is the first European country west of the former Soviet border that is asking for the 'strategic partnership' with Russia (although this strategic partnership will be formalized latter, the document pretentiously named 'Declaration of Strategic Partnership between Serbia and Russia' was signed in May 2013), at the time the ambitions of Moscow were becoming somewhat different and with that also their calculations regarding the Balkan foreign policy vector.

In February 2008, a unilateral declaration of 'Kosovo's independence' was definitely taking place, followed by a frontal 'diplomatic attack' by the entire 'Western bloc' on Serbia's interests. Consequently Serbian public started turning towards Russia, a fact that could not be ignored by any political establishment. Russia's political activity was primarily related to Serbia (due to the favourable 'climate' and the actuality of the Kosovo issue, which was then dealt with by the 'whole world'), although it was also evident in other Balkan countries. Russian investors became present in Montenegro, where on the one hand, they bought a lot of real estate, and on the other hand, the Russian capital entered one of the most important industrial capacities in Podgorica - the Aluminum plant (Kombinat aluminijuma Podgorica). In B\&H and Bulgaria, Russian interests are being realized through the energy sector. The representatives of Zarubezhneft JSC in 2006 signed with the Government of the Republic of Srpska the Protocol on the Process of Privatization of the Petroleum Refinery in Bosanski Brod, of the Oil Refinery in Modrica, as well as of the energy sails company 'Petrol'. Together with Bulgaria, Russia is planning three strategic projects: the construction of the South Stream gas pipeline to Serbia, the Burgas-Alexandroupolis oil pipeline to Greece and the new Belene nuclear power plant (Georgiev, 2009, pp. 3-9). The originally considered route for 'South Stream' stretched from Bulgaria to the north through the territory of Romania to Hungary, but it was changed so that Serbia 'entered the game', which has implications not only in the domain of energy, but also in the domain of geopolitics. In Serbia, in addition to the agreement on the 
strategic pipeline, the privatization of the state oil company NIS has been done (with two refineries, modest - but with its own sources and a huge distribution network), which through different kind of taxes made up 15 $19 \%$ of the state budget, a figure that must be taken into account when talking about the stability of the fiscal system. Although with modest consumption, the FYR Macedonia is one hundred percent 'dependent' on Russian gas (EIA, 2006, ex. 9-15). This will serve for later attempts to include Skopje in the 'Turkish Stream' project. Russian Foreign Minister Sergey Lavrov estimated in May 2015 that behind the demonstrations against the government of Nikola Grueski in Macedonia (which eventually succeed and cause the overthrow of Grueski, who fled to Hungary where he received political asylum) 'stands the United States because of the refusal of the Macedonian government to impose sanctions on Russia and to prevent Skopje's participation in the Turkish Stream gas pipeline project.' (RTS, 2015) Parallel to the strategic plans in the energy sectors (for which it must be said to have been successfully implemented - on January 1, 2021, in the village of Gospođinci in the north of the country the so-called Balkan Stream, $402 \mathrm{~km}$ long, has been officially put into work; the Serbian part of the Turkish Stream has been laid down all the way from the Bulgarian to the Hungarian border: Russian gas came to Serbia and the Republic of Srpska), Russia approved a credit line to Serbia for the revitalization of the railway in the value of 800 million dollars. Thanks to the geographic position of the country and its infrastructure connection, this project will be reflected in the traffics systems in Montenegro, B\&H, (North) Macedonia, and Bulgaria.

In addition, based on a special agreement from 2009, a Russian-Serbian humanitarian centre of regional significance was established in Niš (officially opened in April 2012). For the US, this center, which was established with the aim of acting more efficiently in the event of natural disasters (in which the Russian Ministry of Emergency Situations has vast experience and knowledge, incomparable with similar institutions in other countries) was the 'spy nest', and so periodically there were articles in the media on this subject. US Deputy of the Assistant Secretary of State Brian Hoyt Yee even warned about this very openly during his speech in Congress: 'We share this with the government of Serbia, that Serbia has the full control of its territory and facilities on its territory. If it allows Russia to create some kind of a special centre for espionage or other nefarious activities, it will lose control over part of its territory.' (Djurdjic, 2017) However, the real reason for the concern of American officials is the development of military cooperation between Russia and Serbia. As NATO expanded to Montenegro 
and North Macedonia, thus 'closing the circle' around Serbia, Belgrade and Moscow improved military relations. 'Russia has so far helped (direct aircraft donations and armoured patrol vehicles, favourable terms of purchase or credit) by equipping Serbian armed forces with six MiG-29 planes, 30 armoured patrol and reconnaissance vehicles (BRDM-2MS) and 30 tanks (T-72 MS). Serbia has already purchased four new, Russian helicopters Mi-35M, and three transport helicopters Mi-17, as well as one anti-aircraft system Pancir S-1 (which serves to defend from low-flying objectives and because of its tactical and technical characteristics is currently the best tool for defence from such attacks). The curiosity is also the fact that Russia's sophisticated anti-aviation system S-400 only once in history has been transferred to another country's territory because of a joint military exercise: in Serbia in October 2019.' (Proroković, 2020, pp. 203 - 204) Also, since 2019, when two important strategies - National Security Strategy and Defence Strategy were adopted, Serbian military neutrality became formalized: 'Development of the partnership cooperation of the Republic of Serbia with NATO, based on the policy of military neutrality through the Partnership for Peace and the monitoring position in The Collective Security Treaty Organization (ODKB) contributes to the stability of the Republic of Serbia. For further development of democracy, stability and prosperity of the region, for the Republic of Serbia, it is important to improve relations with the US, Russia, China, and other traditional partners and major factors of the international community.' (National Security Strategy, 2019, p. 6)

Unlike the approach in the first decade of the post bipolar world, since 2006 Russia has started acting somewhat differently in the Balkans, using the issue of energy security as a basis for strengthening its position, and cooperation with Serbia as a means of penetrating not only its energy, but also its political and military influence that will transfer further to the surroundings, primarily to B\&H, Montenegro, and North Macedonia.

\section{NATO AGAINST RUSSIA: THESIS ON THE RUSSIAN MALIGNANT INFLUENCE AND AMERICAN CONTRA MEASURES}

As some previous years were ground-breaking in some respects, so was the year of 2014 due to the escalation of the Ukrainian crisis, which will leave long-term and more significant consequences on international relations (or more precisely - European relations) than it was thought at first. Even before the events on the Kiev Maidan, every action of Russia provoked a counter- 
reaction from the US and (often!) the EU. ${ }^{3}$ For example, during its visit to Sofia in the summer of 2007, Frank G. Wisner as a special US representative of 'Troika' (next to the German diplomat Wolfgang Ischinger and Russian representative Alexander Botsan Kharchenko) in the negotiations on the future status of Kosovo and Metohija called on President Georgi Parvanov to 'Euro-Atlantic solidarity'.

Wisner's mission was well-known in advance. He went to Sofia to put pressure on the Bulgarian state leadership to accept 'new reality' after the unilateral declaration of 'independence' of the Kosovo Albanians, as soon as possible. This was important because of the very resolute announcements of Greece and Romania that they would not do that.

If Bulgaria would stay in the 'bloc' together with Greece and Romania that would complicate the position of the Albanian state-like creation, but it would also further problematized Skopje's decision on that issue (Macedonian Albanians explicitly demanded such a decision with the threat of consequences if it is waited for). However, Wisner used the moment to talk not only about the Kosovo case. It seems this was a second-rate issue for him. Instead, he talked about Bulgaria's three energy arrangements with Russia and the necessity of 'Euro-Atlantic solidarity' in that context! (Proroković, 2018, pp. 668-672) It is worth recalling that after the political changes in 2009, Bulgaria suspended or simply slowed down all three projects, respecting the principle of 'Euro-Atlantic solidarity', although in return it received absolutely nothing in terms of alternative projects for the Burgas-Alexandrouplos pipeline and the Belene nuclear power plant (and what was offered to it as an alternative to South Stream and it concerns the inclusion in the Trans-Adriatic Gas Pipeline and interconnection with Greece and Serbia, is not worth a serious discussion, although it was presented to the Bulgarian public as a realistic substitute for giving up its deals with Russia). Nevertheless, unlike before, after 2014 all US and EU activities aimed at pushing out any Russian influence from the Balkans became completely open, more brutal, without the usual diplomatic phrases and sensitive political formulations. The thesis about 'Russian malignant influence' was launched, and for the sake of fighting it, anti-Russian actions were allowed in all directions. The goal of marking the 'Russian malignant

\footnotetext{
${ }^{3}$ The new version strongly promoted in the English language since 2015 is - Kyiv (transcription from the Ukrainian language), not Kiev (transcription from the Russian language).
} 
influence' as a threat was to legitimize in advance any informative action of Russia and thus make Russia a 'big liar' in international relations.

Despite all the shortcomings and inconsistencies in the process of defining the term 'hybrid war', it is obvious that such an approach is applied, and that NATO is waging a 'hybrid war' in relation to Russia. In that context, the thesis of Russian malignant influence is important both from a tactical and from a strategic point of view. (Kuczyński, 2019, p. 3) In this respect, political relations were also disrupted, as all Balkan states were involved either in the expulsion of Russian diplomats or in exposing 'spy scandals'. The President of Montenegro, Milo Đukanović, went the furthest, accusing Russia of attempting to carry out a coup d'état during the 2016 elections. Other cases of diplomatic incidents are shown in Table no. 2.

After 2014, the United States is fully using the position they have built since the early 1990s, the ties that have been built, and the mechanisms of dependence on the American political mercy or financial aid in order to push out any Russian influence. Thus essentially becoming the only external actor of regional security and gaining the possibility to manage all key political processes in the Balkans through the order of hegemonic stability.

One of the consequences of these American activities (which were to a great extent coordinated with the EU) is suspending of the 'South Stream', its replacement with the 'Turkish stream' and the multi-year postponement of its implementation. Another consequence is the joining of all Balkan states to the Western sanctions against Russia (except, of course, Serbia and thus $\mathrm{B} \& \mathrm{H}$, since the representatives of the Serbian entity are blocking the adoption of such a decision). This practically prevents the expansion of trade exchange and strengthening of economic relations. Finally, all Balkan NATO members take part in military exercises against Russia, which sometimes takes on a grotesque picture. 
TABLE NO. 2: CHRONOLOGY OF DETERIORATING DIPLOMATIC RELATIONS (2016-2020)

\begin{tabular}{|c|c|c|}
\hline State & Diplomatic incident & Time frame \\
\hline Montenegro & $\begin{array}{l}\text { Accusing Russia of a coup d'état } \\
\text { Expulsion of a Russian diplomat }\end{array}$ & $\begin{array}{l}\text { November } 2016 \\
\text { March } 2018\end{array}$ \\
\hline Albania & Expulsion of two Russian diplomats & March 2018 \\
\hline Croatia & Expulsion of a Russian diplomat & March 2018 \\
\hline North Macedonia & Expulsion of a Russian diplomat & March 2018 \\
\hline Romania & Expulsion of a Russian diplomat & March 2018 \\
\hline Greece & Expulsion of two Russian diplomats & July 2018 \\
\hline Bulgaria & $\begin{array}{l}\text { Expulsion of a Russian diplomat } \\
\text { Expulsion of two Russian diplomats }\end{array}$ & $\begin{array}{c}\text { October } 2019 \\
\text { September } 2020\end{array}$ \\
\hline Serbia & $\begin{array}{l}\text { Charges against the Russian deputy } \\
\text { military attache of spying (he had } \\
\text { already left the country) }\end{array}$ & November 2019 \\
\hline $\mathrm{B} \& \mathrm{H}$ & $\begin{array}{l}\text { The absence of two members of the } \\
\text { Presidency at the meeting with the } \\
\text { head of Russian diplomacy in Sarajevo }\end{array}$ & December 2020 \\
\hline
\end{tabular}

The naval exercises 'Breeze 2020' brought both Greek and Turkish warships to the port of Burgas (Bulgaria), although at that time GreekTurkish relations were heated due to the conflict over exploitation rights in the Mediterranean (natural gas exploitation rights). (US Embassy in Bulgaria, 2020) So, even though bilateral relations were bad, it did not affect relations with Russia because the course is determined by the United States.

The United States defines its attitude towards Russia primarily through the prism of its long-term geopolitical goals. The key instrument in achieving these goals is NATO. Rearranging Ukraine on the 'anti-Russian track', as was previously done in Georgia, and which will be done in the coming years in Moldova, while trying to implement regime change in Belarus and problematizing relations in Russia's immediate vicinity wherever possible 
(for example - between Armenia and Azerbaijan) indicates that the focus of US action through NATO structures has shifted to the immediate Russian border, to the post-Soviet space.

Looking from that angle, the Balkan Peninsula should have already been a secured 'NATO zone', a geographical region in which the United States will be not only the most important, but also the only guarantor of regional security. Russia's attempt to 'come back', noticeably strengthening its influence since 2006, primarily through 'energy projects', but also relying on international agreements that guarantee its position as a significant player in regional relations, is an obstacle for NATO, as it slows down its further 'progress on the Eastern Front' and coordination of pressures on the immediate Russian border, in the post-Soviet space.

Hence, the 'discipline' of the Balkan states through demands to expel Russian diplomats (due to the alleged poisoning of retired Soviet agent Sergei Skripal who fled to Great Britain two decades ago!?); revealing of 'spy scandals' and 'coups'; demands to participate in joint military exercises directed completely against Russia (for the US, it would be absolutely no problem to connect the military forces of Serbia and the so-called Republic of Kosovo in the same way as connecting Greece and Turkey in naval exercises, since it is in the 'broader interest' of the fight for 'democratic values' against Russian malignant influence); constant expression of 'Euro Atlantic solidarity' even when it comes at its own cost (like in the case of Bulgaria). All that concerns Russia is or will be problematized, including energetic cooperation, economic ties, and cultural exchange. The thesis on the fight against the Russian malignant influence, which is almost proclaimed as a threat to the achieved 'civilization development', is only a 'political frame' to explain the broader context of a need to align the Balkan states with the US.

\section{CONCLUSION}

The Balkan Peninsula has a certain strategic importance, both for NATO and for Russia. During the transformation of the structure of the world political system from bipolar to unipolar, in the 1990s, this geographical region became the scene of armed conflicts and a region of marked destabilization, which attracted the attention of all important actors in international relations.

Complex mutual relations of the newly formed states after the disintegration of communist Yugoslavia, mistrust between the constituent 
nations within those states, historical heritage, but also the unwillingness of the international community to react adequately and in time, in certain situations made the 'Balkan crisis' last longer than a quarter of a century, despite all the peace agreements, and the (partial) expansion of NATO and the EU to this region.

Burdened by the painful consequences of the collapse of the Soviet Union, Russia in the 1990s largely limited itself to using political means and mechanisms to influence regional relations. Russia's goal was to reach solutions in accordance with the principles of international law (inviolability of the external borders of the newly formed states and allowing as little interference of Western actors in internal affairs as possible) and thus maintaining certain principles according to which regional relations would be regulated in the long run. Such an approach could have been maintained until 1999, but, as time has shown, not after it. NATO's aggression on the FR Yugoslavia determined the further positioning of the United States not only in the Balkans but also in the entire (Southeastern) Europe and Eastern Mediterranean, as would show further activities in the Caucasus, Ukraine, Belarus and Moldova, but also in Iraq and Syria. The reconfiguration of the post-Yugoslav space projected by the United States included the final separation of Serbia-Montenegro, acceptance of the 'reality' of 'Kosovo's independence', and then a derogation from the Dayton Agreement and internal reform in Bosnia and Herzegovina, all with full control of the Balkans and with NATO's expansion to all Balkan states. That is why this region remained the only area to which NATO continuously expanded until 2020 when North Macedonia was admitted to membership. For Russia, such US plans and NATO expansion presented a problem for several reasons.

First, placing the Balkans under the complete control of the United States also meant that the focus of NATO's geopolitical activities shifted farther east, to the post-Soviet space, to Russia's immediate border zone. The unlimited and immediate expansion of NATO also meant a defensive attitude of Russia in every respect.

Second, the rejection of all the principles on which the disintegration of multinational communist countries took place (which the United States de facto did by allowing Albanians to unilaterally declare independence in Kosovo) may be an introduction to a great nightmare not only in the postYugoslav but also in post-Soviet space. Such a nightmare would mean longterm destabilization in the immediate vicinity of Russia, possibly also within the country, which prevents any development (economic, social, cultural, etc.) and induces crises with unforeseeable outcomes. For NATO expansion, 
'crisis management' with the imposition of solutions (up to down) and the creation of 'new realities' is a way to achieve hegemonic stability through the construction of projected regional orders. For Russia, however, this represents a first-class threat, and that is why Russia's position is a 'firm persistence' both on respect for the Dayton framework and on UN Security Council Resolution 1244 (1999).

Third, in the existing circumstances, and after the escalation of the Ukrainian crisis in 2014, Serbia has practically remained the only Balkan ally of Russia. Undoubtedly, Russia has invested in this alliance, just as Serbia, under the slogan of conducting a 'multi-vector foreign policy', constructed a certain political framework for cooperation with Russia, regardless of its obligations to the EU. However, it is more than noticeable that Serbia is a 'target' of continuous and coordinated pressure from the United States and the European Union to change its position and abandon the 'multi-vector approach'.

Somewhat similar to Serbia, although it was less pronounced in every respect and realized in different circumstances, until 2014 the officials of Montenegro and North Macedonia also spoke of excellent ties with Russia. But, since then, a lot has changed, including the strategic determination and foreign policy priorities, and from 'excellent relations' with Russia, they have come to NATO membership, expelling Russian diplomats and establishing sanctions against Russia. For Serbia, giving up the alliance with Russia would mark the beginning of a 'geopolitical catastrophe' from which it would be difficult to recover in every respect, but such a development of the situation would certainly harm Russia as well. First and foremost, this would reflect on a political, or more precisely psychological plan because it would pose a question of Russia's capabilities to defend its allies. NATO's expansion on Serbia would also leave very tangible consequences to Russia's political reputation and the possibility to renew its influence in Southeast Europe. Due to the above, it is possible to state that Russia cannot peacefully observe NATO's expansion into the Balkans, nor choose a strategy of nonreaction regarding the processes concerning the US's attempt to become the only guarantor of regional security in this part of the continent. Since 2006, Russia has projected a 'comeback' to the Balkans through the expansion of cooperation in the fields of energy, but also the connection of railway infrastructure and the increase of trade exchange. However, after 2014, that proved to be insufficient, since Russian actions provoked very aggressive counter-reactions from the US (and the EU which followed the US). Although the 'Balkan issue' is no longer as important to the United States 
as it was in the 1990s, the impossibility to 'close the issue' through fully legitimizing the new regional order (which includes 'independent Kosovo') somewhat problematizes the operationalization of their plans in the postSoviet space.

Therefore, the US will 'remain active' in the Balkans, and in certain development of a situation this region may gain significance in some potential political and economic negotiations between Washington and Moscow. The signing of the so-called 'Washington Agreement', on many issues controversial statements of wills between the Prime Minister of Kosovo Avdullah Hoti and the President of Serbia Aleksandar Vučić with the mediation of Donald Trump, shows that the Balkans, and above all 'the problematic Serbia', remain in the US's line of sight (although it could be more accurately called a 'peripheral zone'). The document also explicitly mentions the issue of 'energy security', which once again indicates the 'unacceptability' of further expansion of Russian influence through energy cooperation.

Hence the increasingly aggressive action, which after the accession of Montenegro and North Macedonia to NATO is mainly directed towards Serbia. On the other hand, for Russia, the success of the United States and the completion of NATO expansion in the Balkans would bring certain threats and challenges, or more precisely - it would make the existing threats more dangerous, and the existing challenges - more explicit. So, on the one hand, the United States has no interest in stopping the planned expansion, while on the other hand, Russia is not in a position to allow them to do so. Because of everything, the Balkans remain a region where the establishment of a kind of balance of power between NATO and Russia is being monitored.

\section{REFERENCES}

Ahrens, G. H. (2007). Diplomacy on the Edge: Containment of Ethnic Conflict and the Minorities Working Group of the Conferences on Yugoslavia. Washington, Woodrow Wilson Center Press.

Bildt, C. (1998). Peace Journey: The Struggle for Peace in Bosnia. London, Weidenfeld\&Nicolson.

Declassified Documents Concerning Russian President Boris Yeltsin. Clinton Digital Library. (2018), retrieved from https://clinton. presidentiallibraries.us/items/show/57569. Accessed 8 January 2021. 
Djurdjic, M. (2017, June 15). US Sees Russia's 'Humanitarian Center' in Serbia as Spy Outpost, retrieved from https://www.voanews.com/ europe/us-sees-russias-humanitarian-center-serbia-spy-outpost. Accessed 18 November 2020.

EIA (2006). Russia Energy Data, Statistics and Analysis - Oil, Gas, Electricity, Coal, retrived from http://www.eia.doe.gov/cabs/Russia/Full.html. Accessed 15 November 2020.

Gajic, S.\& Ponomareva, E. (2020). Accelerated expansion of NATO into the Balkans as a consequence of Euro-Atlantic Discord. Вестник МГИМО Университета, 2, pp. 70-93.

Georgiev, A. (2009). Bugarsko viđenje energetskih pitanja jugoistočne Evrope. [Bulgaria's view of energy issues in Southeast Europe], in: Šesti izveštaj projekta praćenja rusko-srpskih odnosa (pp. 41-49). ISAC fund.

Hoxha, E. (1979). Reflections on China II, 1973 - 1977, extracts from the political diary. Tirana, The Institute of Marxist - Leninist Studies at the Central Comimittee of the Party of Labour of Albania - 8 Nëntori.

Jovanović, Ž. (2006). Kosovsko ogledalo. [Kosovo mirror]. Beograd, Beogradski forum za svet ravnopravnih.

Kecmanović, N. (2017). Hronika nemoguće države. [Chronicle of an impossible state]. Beograd, Catena Mundi.

Kuczyński, G. (2019). NATO - Russia relations: the return of the enemy. Warsaw Institute, Warsaw.

Mitić, M. (2003). Kako nam se dogodio Rambuje. Beograd, Filip Višnjić.

Ponomareva, E. (2020). Quo Vadis, Serbia? Russia in Global Affairs, 69(1), pp. 158-179.

Ponomarjova, E. (2019). NATO agresija protiv Jugoslavije: dvadeset godina kasnije [NATO aggression against Yugoslavia: twenty years later]. Argumenti, 13(38), pp. 9-44.

Proroković, D. (2020). Russian vector in Serbian Politics: impacts and outcomes on regional relations, in: Ana Jović - Lazić \& Alexis Troude (Eds). Security Challenges and the Place of the Balkans and Serbia in a Changing World (pp. 196-211). Belgrade, Institute of International Politics and Economics.

Proroković, D. (2019). Proces u Rambujeu - politička priprema agresije NATO na SR Jugoslaviju. Politika nacionalne bezbednosti, X (16), pp. 237-252.

Proroković, D. (2018). Geopolitika Srbije. [Geopolitics of Serbia]. Belgrade, Službeni glasnik. 
Rossiya 24 (2020). Документальный фильм Курск. Десять дней, которые потрясли мир (Авторы сценария: Андрей Медведев и Татьяна Саломадина) [Documentary movie - Kursk. Ten days that shook the world], retrived from https://www.youtube.com/watch?v=PUS3F8 wnIxM. Acceseed 04 November 2020.

RTS (2015 May 22). Makedonija mesto novog sukoba SAD i Rusije. [Macedonia, a place of new conflict between USA and Russia], retrived from https://www.rts.rs/page/stories/ci/story/3/region/1927593/ blumberg-makedonija-mesto-novog-sukoba-sad-i-rusije.html?email =yes. Accessed 07 December 2020.

Staniszkis, J. (2001). Postkomunizm: próba opisu. [Post-communism: an attempt at description]. Warszava, Wyd, słowo/obraz teritoria.

Stanković, Đ. (2009). Srbija i stvaranje Jugoslavije. [Serbia and the creation of Yugoslavia]. Beograd, Službeni glasnik.

Strategija nacionalne bezbednosti Republike Srbije (2019). [National Security Strategy of the Republic of Serbia]. Narodna skupština Republike Srbije, Beograd.

US Embassy in Bulgaria (2020). Breeye 2020. Annual naval exercise of Bulgarias Black Sea coast. 10.07.2020, retrived from https://bg. usembassy.gov/ breeze-2020-annual-naval-exercise-of-bulgarias-blacksea-coast/. Accessed 01 November 2020.

Voltskaya, T. (2020, August 12). Спасти людей или сохранить лищо. 20 лет со дня гибели подлодки Курск. [Save people or save face. 20 years since the sinking of the submarine Kurska]. Sever Real, retrieved from https:/ / www.severreal.org/a/30778621.html. Accessed 04 November 2020. 